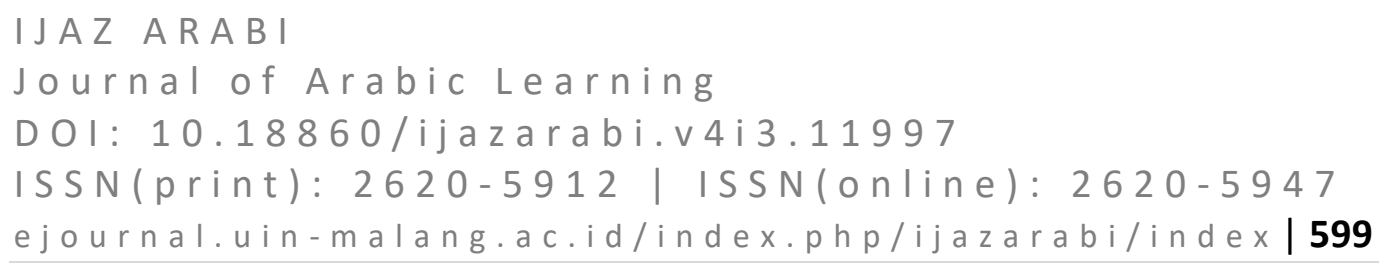

\title{
Challenges and Expectations of Online Arabic Language Teaching In The Covid-19 Pandemic Era
}

\author{
AL-Muslim Mustapa ${ }^{1}$, Mohd Faizulamri Mohd Saad², \\ Mohamad Zulkifli Abdul Ghani ${ }^{3}$ \\ The National University of Malaysia, Malaysia ${ }^{1,2,3}$ \\ almuslim@ukm.edu.my ${ }^{1}$, faizam7879@yahoo.com², zulghani@ukm.edu.my ${ }^{3}$
}

\begin{abstract}
The Covid-19 pandemic has changed the educational landscape around the world. In this era, higher education institutes offer fully online teaching and learning delivery as an alternative implementation. During the transition period, faculty and students experimented extensively to adapt to the new norms of education. This paper aims to reveal the positive academic experiences of Arabic language teachers during the past semester and their challenges. Belief in one's ability and readiness to face the coming day is essential for the following action plan by those in charge. It becomes an indicator for individuals to equip themselves and not be adequate with existing skills. Data were obtained through a questionnaire instrument to 12 respondents of Arabic language instructors and then analyzed based on the Fuzzy Delphi method. The study lists five (5) positive experiences and three (3) most fundamental challenges of online teaching. Belief in the readiness of implementing online teaching for the coming semester was also expressed. The actual situation of the teaching staff is an essential indicator in evaluating the effectiveness and quality of delivery during the Covid-19 pandemic. The educational landscape is far from changing and will never return to how it was before.
\end{abstract}

Keywords: Online Teaching; Arabic Teaching and Learning; language instructors; New Norms; Challenges.

\section{INTRODUCTION}

The covid-19 pandemic has significantly impacted daily life globally. Various aspects of life were affected. Education is one of the most affected sectors around the world. Formal and non -formal education is facing drastic changes. The United Nation (2020) reports the closure of educational institutions, including universities in 190 countries and 94 percent of the millions of the student population affected their studies due to covid-19. Most countries, including Malaysia, have taken alternative measures after the closure of higher education institutions (HEIs), by changing the delivery system of face-to-face approach to distance learning. The third wave of covid-19 transmission saw the closure of HEIs once again into an indefinite period. The approach of HEIs with the delivery of distance education has led to educational technology and the internet to a level never seen before. HEIs have shown a quick response to find solutions and adapt to new situations to 


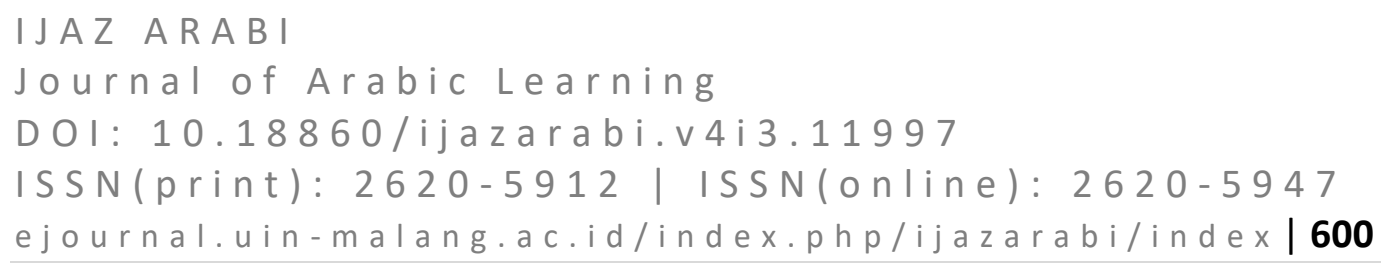

continue teaching and learning activities despite facing various difficulties. Initially, the situation was perceived as crisis time management. Now, such management is turning into a new normal of higher education (International Association of Universities (IAU) \& Erasmus Student Network (ESN), 2020). The World Bank (2020) reports that educational institutions have taken 5 key actions. 1) Short -term actions such as setting up a helpline, and medium-term such as adding related capacity. 2) Make full use of existing facilities such as cloud systems and mobile communication equipment. 3) Set up resource centers and assistance to administration, faculty, and students. 4) Re-evaluate existing resources and their applicability, and 5) communicate with faculty, students, and others to provide guidance.

In Malaysia, HEI Teaching Centers play an important role in the transmission of face -to -face teaching to virtual teaching or online teaching. When Covid-19 erupted, half of IPTs such as The National University of Malaysia was in the process of migrating to a new learning management system, UKMFolio. In this situation, the average instructor and student are still raw with this system. The proactive action of UKM Teaching in providing continuous guidance has helped lecturers and students to adapt to new approaches and technologies for the continuity of education.

Despite the successful preparation and rapid adaptation to the new norms of the national education sector, difficulties and problems still arise. The mass media reported several cases of students climbing trees and hills to gain internet access points to the constraints in place. While it may be isolated, it is feared the tip of the iceberg signal turns into an actual situation. This raises questions about the quality of teaching delivery. The Covid-19 crisis has spurred innovation in education. Apps for learning saw rapid feature updates, teachers actively publishing learning videos, interactive content building workshops were popular, gadgets and mobile gadgets sold out in the market, so buyers had to wait for stock, but it also posed challenges and constraints. Some children and adolescents who are affected by the lack of resources and environment to gain access to sound learning as well as teachers who are distraught and need training and support to adapt to new approaches to teaching (World Bank, 2020). This shows that teachers also face their own challenges and constraints in delivering effective education amid these pandemic situations. This situation, if left untreated, can affect the quality and objectives of education as teachers play an important role in their success. Therefore, exploratory studies should be carried out to explore in order to identify the challenges and constraints. Effective follow-up solution actions depend on knowledge of the actual problem occurring.

Several studies have been conducted to assess the challenges and readiness of instructors in facing this crisis as studied by Adedoyin \& Soykan, (2020), Bisht, Jasola, \& Bisht, (2020), Huang, (2020), Maatuk, Elberkawi, Aljawarneh, Rashaideh, \& Alharbi, (2021) and Paudel, (2021). However, none of them focuses about teaching Arabic from the perspective faced by the Arabic teachers, especially 
Journal of Arabic Learning

DOI: $10.18860 / \mathrm{ijazarabi.v4i3.11997}$

ISSN(print): $2620-5912$ | ISSN(onIine): $2620-5947$

ejournal.uin-malang.ac.id/index.php/ijazarabi/index/ 601

HEIs in Malaysia. This study exposes the challenges, constraints and readiness of Arabic teachers where past studies were not investigated. This paper aims to reveal the situation from the perspective of Arabic language instructors at National University of Malaysia (UKM), when faced with changes in educational modes due to the Covid-19 pandemic. Their positive experiences and challenges were gained to provide insights as well as the support and assistance needed. The world of education, including Arabic language education is certainly different from before and is unlikely to return. Therefore, preparation and anticipation are very necessary.

\section{METHOD}

Based on the main objectives of the study, there are three main objectives set.

1. Identifying the positive teaching experiences experienced by Arabic language instructors throughout the conduct of distance teaching

2. Identifying the challenges faced by Arabic language instructors throughout the conduct of distance teaching

3. Exploring the belief in readiness implements upcoming online teaching

This study takes a qualitative-quantitative hybrid approach. Data were obtained through a questionnaire based on 7 Likert scales and containing 3 sections. The first part is the advantages of online teaching during the Movement Control Order (MCO), the second part challenges online teaching during the $\mathrm{MCO}$, and the last part is an open-ended question aimed at gaining more in-depth information. The questions were adapted from the study of Paudel (2021) and modified based on the objectives and situation of the study. Questionnaires built in google form were given to 17 language instructor respondents. Only 12 respondents answered and were accepted by the researcher.

The obtained data were analyzed through Fuzzy Delphi method. For that, the Likert scale value will be converted to the Fuzzy scale value. Then the defuzzification process is done to obtain a Fuzzy score. It is the process of determining the ranking or priority of each item. The top five (5) items from each category were taken for the study findings. Content and thematic analysis were also performed on qualitative data from open-ended questions. The respondents of this study were identified as R1 to R12. 


\section{IJAZ ARABI}

Journal of Arabic Learning

DOI: $10.18860 / \mathrm{ijazarabi.v4i3.11997}$

ISSN(print): 2620-5912 | ISSN(onIine): 2620-5947

ejournal.uin-malang.ac.id/index.php/ijazarabi/index/602

\section{RESULTS AND DISCUSSION}

The findings obtained were arranged based on the three objectives of the study. Findings are presented and interspersed with brief discussions.

\section{The Positive Distance Teaching Experiences Of Arabic Language}

Findings of the five teaching experiences (Table 1.). Respondents preferred flexibility when working throughout the MCO period. The primary task of being a teacher is no longer tied to the time and place of lecture like traditional teaching before. It can be done with mobile technology. Therefore, teaching becomes more accessible. All teaching requirements such as course materials and test instruments are at your fingertips and can be achieved even at home. This experience is well known among researchers. Various studies in mobile technology-based learning have been done to enable learning to happen 'anywhere and anytime'. Such learning can facilitate communication, collaboration, and creativity among participants in the context of appropriate use (Kumar \& Mohite, 2017; Lee \& Chan, 2007; Traxler, 2009). Thus, such a positive experience is in anticipation. The difference is that respondents acquire these positive experiences and beliefs forcibly through instructions that need to be followed. This is one of the positive things behind the Covid-19 pandemic. Respondents were forced to move to adapt toward more flexible learning, accept online learning, and explore hybrid learning, a combination of synchronous learning and asynchronous learning. These changes certainly open up new landscapes of thinking and experience about teaching and learning (Marinoni, Van't Land, \& Jensen, 2020)

Table 1. Positive Teaching Experiences

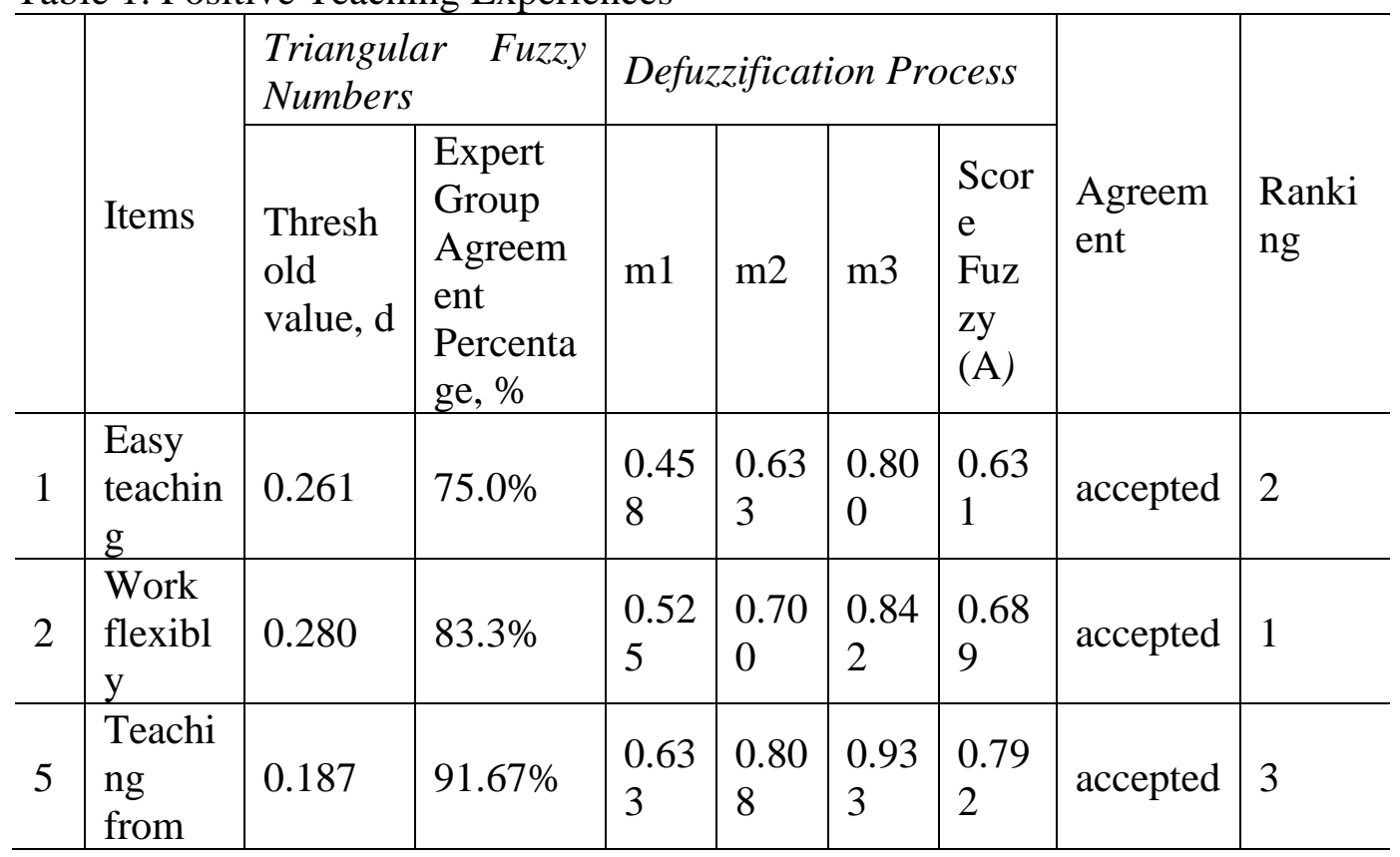


Journal of Arabic Learning

DOI: $10.18860 / \mathrm{ijazarabi.v4i3.11997}$

ISSN(print): $2620-5912$ | ISSN(onIine): $2620-5947$

ejournal.uin-malang.ac.id/index.php/ijazarabi/index/603

\begin{tabular}{l|l|l|l|l|l|l|l|l|l}
\hline & $\begin{array}{l}\text { the } \\
\text { house }\end{array}$ & & & & & & & & \\
\hline $\begin{array}{l}\text { Life- } \\
1\end{array}$ & $\begin{array}{l}\text { long } \\
\text { learnin } \\
\mathrm{g}\end{array}$ & 0.252 & $75.00 \%$ & $\begin{array}{l}0.54 \\
2\end{array}$ & $\begin{array}{l}0.71 \\
7\end{array}$ & $\begin{array}{l}0.85 \\
8\end{array}$ & $\begin{array}{l}0.70 \\
6\end{array}$ & accepted & 5 \\
\hline $\begin{array}{l}\text { Conne } \\
\text { ct with } \\
\text { the } \\
\text { world }\end{array}$ & 0.235 & $83.33 \%$ & $\begin{array}{l}0.57 \\
5\end{array}$ & 0.75 & 0.88 & 0.73 & 6 & accepted & 4 \\
\hline
\end{tabular}

The Challenges Of Distance Teaching Faced By The Arabic Language

In addition to the experiences and benefits behind online teaching, respondents also faced several challenges. The respondents agreed upon three main challenges. Internet access, time management, and no specific online teaching guide (Table 2.). Internet access has become a concern of many about the effectiveness of online teaching. For example, the Malaysian Communications and Multimedia Commission (MCMC, 2020) has issued an official statement on the increase in internet usage by $23.5 \%$ in the first week of MCO. This condition causes congestion and leads to a decrease in speed. The International Association of Universities (IAU) (Marinoni et al., 2020) divides this problem into three categories. First, that HEIs cannot implement online teaching because students do not have internet access, as in Africa. Second, the category of HEIs in countries with good access. However, it is noted that some of these HEIs do not have adequate infrastructure or equipment. Similarly, some IPTs face the problem of fair teaching delivery because not all students have access to the internet.

At the same time, respondents had to be independent in learning pedagogy and online teaching skills. The drastic change from traditional teaching to online caused respondents to take a "learning by doing" approach to continue teaching. This situation is challenging and requires effective time management. Teaching and learning are chasing at the same time. In addition to the curfew with family members. Work and personal assignments need to be managed at the same time and place.

Table 2. Online Teaching Challenges

\begin{tabular}{|c|c|c|c|c|c|c|c|c|}
\hline \multirow[b]{2}{*}{ Items } & \multicolumn{2}{|c|}{$\begin{array}{l}\text { Triangular Fuzzy } \\
\text { Numbers }\end{array}$} & \multicolumn{4}{|c|}{ Defuzzification Process } & \multirow[b]{2}{*}{$\begin{array}{l}\text { Agreem } \\
\text { ent }\end{array}$} & \multirow[b]{2}{*}{$\begin{array}{l}\text { Ranki } \\
\text { ng }\end{array}$} \\
\hline & $\begin{array}{l}\text { Thresh } \\
\text { old } \\
\text { value, } \\
\text { d }\end{array}$ & $\begin{array}{l}\text { Expert } \\
\text { Group } \\
\text { Agreem } \\
\text { ent } \\
\text { Percenta } \\
\text { ge, \% }\end{array}$ & $\mathrm{m} 1$ & $\mathrm{~m} 2$ & $\mathrm{~m} 3$ & $\begin{array}{l}\text { Scor } \\
\text { e } \\
\text { Fuz } \\
\text { zy } \\
\text { (A) }\end{array}$ & & \\
\hline
\end{tabular}




\section{IJAZ ARAB I}

Journal of Arabic Learning

DOI: $10.18860 / \mathrm{ijazarabi.v4i3.11997}$

ISSN(print): 2620-5912 | ISSN(onIine): 2620-5947

ejournal.uin-malang.ac.id/index.php/ijazarabi/index | 604

\begin{tabular}{l|l|l|l|l|l|l|l|l|l}
\hline 2 & $\begin{array}{l}\text { Time } \\
\text { manage } \\
\text { ment }\end{array}$ & 0.192 & $91.7 \%$ & $\begin{array}{l}0.6 \\
00\end{array}$ & $\begin{array}{l}0.7 \\
92\end{array}$ & $\begin{array}{l}0.9 \\
25\end{array}$ & $\begin{array}{l}0.77 \\
2\end{array}$ & $\begin{array}{l}\text { accepte } \\
\mathrm{d}\end{array}$ & 2 \\
\hline 8 & $\begin{array}{l}\text { own way } \\
\text { of } \\
\text { teaching }\end{array}$ & 0.236 & $75.00 \%$ & $\begin{array}{l}0.4 \\
58\end{array}$ & $\begin{array}{l}0.6 \\
42\end{array}$ & $\begin{array}{l}0.8 \\
17\end{array}$ & $\begin{array}{l}0.63 \\
9\end{array}$ & $\begin{array}{l}\text { accepte } \\
\mathrm{d}\end{array}$ & 3 \\
\hline 1 & $\begin{array}{l}\text { Stable } \\
\text { internet } \\
\text { at home }\end{array}$ & 0.057 & $\begin{array}{l}100.00 \\
\%\end{array}$ & $\begin{array}{l}0.8 \\
50\end{array}$ & $\begin{array}{l}0.9 \\
75\end{array}$ & $\begin{array}{l}1.0 \\
00\end{array}$ & $\begin{array}{l}0.94 \\
2\end{array}$ & $\begin{array}{l}\text { accepte } \\
\mathrm{d}\end{array}$ & 1 \\
\hline
\end{tabular}

\section{Exploring The Belief In Readiness Implements Upcoming Online Teaching}

As the Covid-19 pandemic was spreading and the IPT administration decided that teaching was no longer face-to-face but online, respondents were faced with a similar perception. They feel anxious and confused by the situation of the new method of delivery. R11 expressed surprise that online teaching required him to learn many new things. While online learning is not a new thing, especially after the popularity and widespread involvement of MOOCs (Massive Open Online Courses), the fact is that it was previously not a mainstream mode of teaching (AlRahmi, Aldraiweesh, Yahaya, Kamin, \& Zeki, 2019; Hidalgo \& Abril, 2020; Pal \& Vanijja, 2020). The teaching of Arabic before the pandemic was indeed conducted face-to-face and traditionally. There is encouragement to modernize teaching, yet it is an option, and many are comfortable with the status quo. Thus, a respondent (R8) stated that finding new material is his earliest action after receiving the instruction.

The initial reaction of the respondents as a whole was negative. However, they were found to be able to cope well and positively. Throughout the online teaching, respondents were always prepared (R4), did not face any problems (R3), optimistic (R8) and managed to organize the teaching well (R9). Even R1 and R5 expressed happiness while performing the task. This situation continues until the end of the semester. Refer to Figure 1. and Figure 2. for comparison.

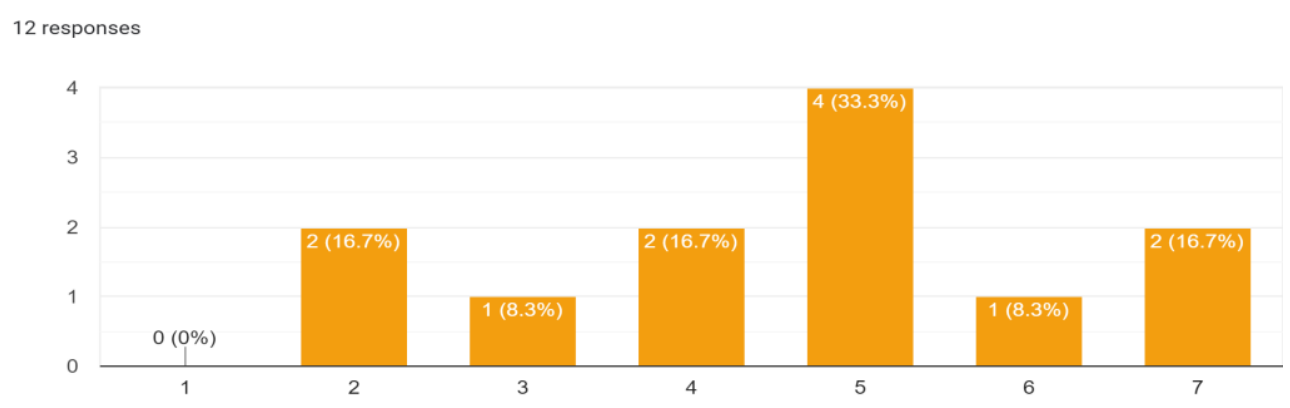

Figure 1. Respondents' Beliefs Prior to Online Teaching

Scale 1 - 7 (Highly Skilled - Highly Unskilled) 
Figure 1. showed the level of respondents' confidence in their ability to implement online teaching when the instructions were first issued by the administration. None of the respondents stated that he was highly capable to deliver online teaching. Most respondents chose to label their ability in delivering online teaching at medium and low levels.

12 responses

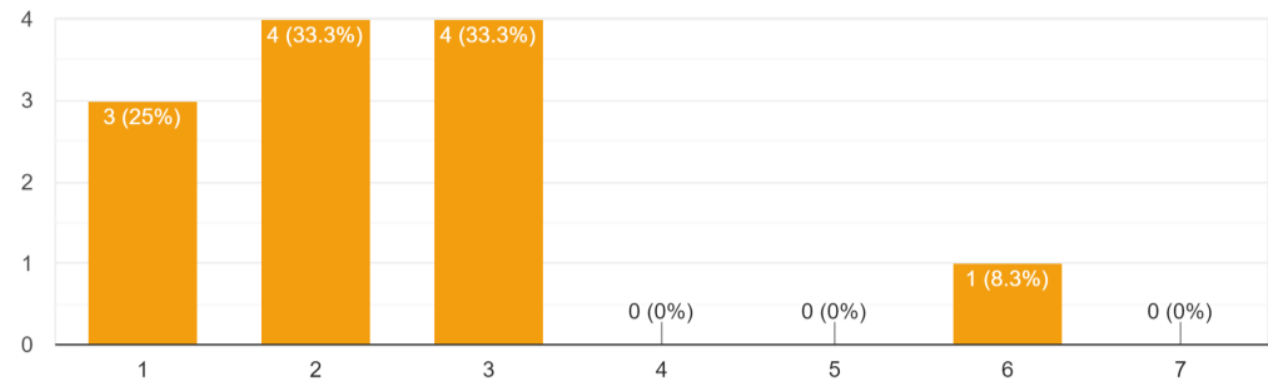

Figure 2. Respondents' Beliefs in Online Teaching (After) Scale 1 - 7 (Highly Skilled - Highly Unskilled)

Figure 2. showed significant changes in response among the respondents after having experienced conducting online teaching completely for the first time. Most respondents expressed an utmost confidence in their ability to teach online completely. However, this situation did not succeed in cultivating the confidence in the respondents to once again face the situation of fully online delivery. Ten (10) out of twelve (12) respondents opted for face-to-face teaching as opposed to online teaching if given the choice (Figure 3.). The main issue raised was the lack of interaction between students and teachers.

'The teaching of language skills must be done face-to-face because instructors are happy to correct students' mistakes face-to-face ... '

(R5)

'Students can interact with the instructors directly and ask directly if they have any doubts about what is being taught. Students are more actively involved through face -to -face discussions '

(R7)

'In class, we know what students want, understand it or not! And so on ' (R12) 


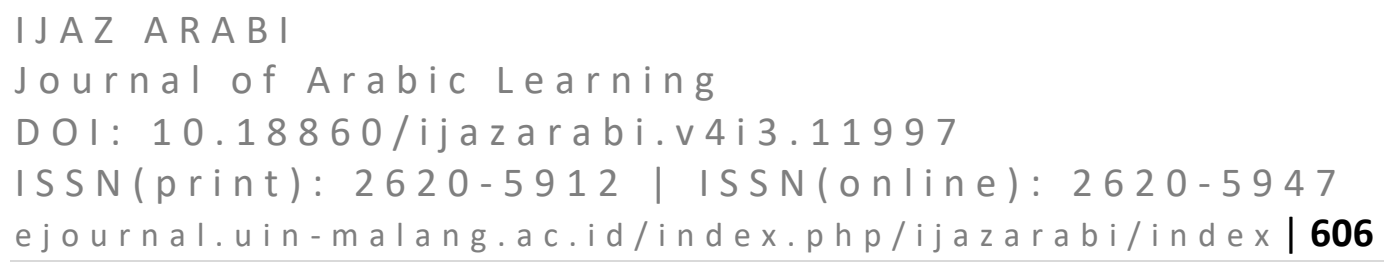

If you were given a choice next semester after the Covid 19 pandemic was over, between continuing to implement online teaching and face -to -face teaching, what would be your choice? 12 responses

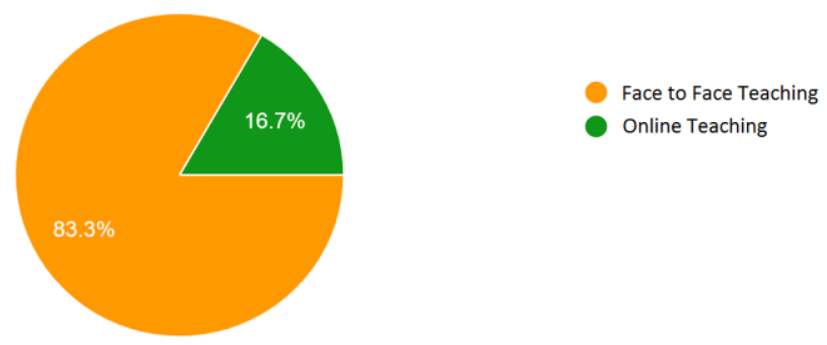

Figure 3. Selection of Online or Face-to-Face Teaching

Figure 3. showed ten (10) out of twelve (12) respondents opted for face-to-face teaching as opposed to online teaching if given the choice. Findings of other factors were voiced by respondents such as internet problems, teaching satisfaction and suitability with Arabic language subjects. But the fact is, the problems mentioned are closely related to the lack of interaction posed by the majority of respondents. Although the interaction is important in the relationship of teaching and learning Arabic, it should take place according to the right approach. Lack of interaction does not mean students do not learn. According to Krashen (1982), students do not need a large interaction rate for language acquisition. But they require a large input rate. The input in language acquisition is on listening and reading. Therefore, he argues, online learning can benefit students by reducing traditional interactions and providing opportunities for more effective learning. This was evident when the study of Wargadinata, Maimunah, Febriani, \& Humaira, (2020) on Arabic language learning revealed the most popular learning material during the Covid-19 pandemic was video. Thus, despite the lack of student-teacher interaction that had to be faced, Arabic language learners actually had the opportunity to receive important and easily accessible language acquisition inputs. Online learning gives an advantage to the new generation of students who often use online tools and online materials. They are known as digital natives (Averkieva, Kachalov, \& Author, 2020). Students are now consumers of technology and they were already tech-savvy when entering university (Junco, Merson, \& Salter, 2010; Mohd Amir, Mohd, Saad, Abu Seman, $\&$ Tuan Besar, 2020). Therefore, the problems faced by Arabic language teachers may be an advantage to the students.

\section{CONCLUSION}

The covid-19 pandemic has caused a crisis in world education, including Arabic language education. Traditional face-to-face teaching was utterly transformed into online teaching. Arabic language instructors face difficulties in fulfilling their respective roles and tasks. Learning online teaching pedagogy and 


\section{IJAZ ARABI}

Journal of Arabic Learning

DOI: $10.18860 / \mathrm{ijazarabi.v4i3.11997}$

ISSN(print): $2620-5912$ | ISSN(online): $2620-5947$

ejournal.uin-malang.ac.id/index.php/ijazarabi/index

adapting simultaneously with teaching is a significant challenge exacerbated by internet access and time management during work from home mode. From another aspect, online teaching offers other benefits, such as flexible hours. Concerns of Arabic language instructors on the effectiveness of teaching were also voiced. However, it has to be accepted as a new norm in education and should be weighed against the benefits of online learning.

Arabic language instructors were found to be successful in overcoming the challenges of online teaching despite initial doubts. However, this success could not convince them to conduct online teaching in the following semester again. Unfortunately, the covid 19 pandemic did not show a solution shortly. Continuing teaching and learning online is better than postponing it to an uncertain time..

\section{REFERENCES}

Adedoyin, O. B., \& Soykan, E. (2020). Covid-19 pandemic and online learning: the challenges and opportunities. Interactive Learning Environments, O(0), 113. https://doi.org/10.1080/10494820.2020.1813180

Al-Rahmi, W., Aldraiweesh, A., Yahaya, N., Kamin, Y. Bin, \& Zeki, A. M. (2019). Massive open online courses (MOOCs): Data on higher education. Data in Brief, 22, 118-125.

Averkieva, L., Kachalov, N., \& Author, C. (2020). Internet technologies in foreign language learning. International Journal of Social Sciences and Humanities, 4(2), 50-56. Retrieved from https://doi.org/10.29332/ijssh.v4n2.405

Bisht, R. K., Jasola, S., \& Bisht, I. P. (2020). Acceptability and challenges of online higher education in the era of COVID-19: a study of students' perspective. Asian Education and Development Studies, ahead-of-print(ahead-ofprint). https://doi.org/10.1108/AEDS-05-2020-0119

Hidalgo, F. J. P., \& Abril, C. A. H. (2020). MOOCs: Origins, concept and didactic applications: A systematic review of the literature (2012-2019). Technology, Knowledge and Learning, 25(4), 853-879.

Huang, J. (2020). Successes and Challenges: Online Teaching and Learning of Chemistry in Higher Education in China in the Time of COVID-19. Journal of Chemical Education, 97(9), 2810-2814. https://doi.org/10.1021/acs.jchemed.0c00671

International Association of Universities (IAU), \& Erasmus Student Network (ESN). (2020). COVID-19 impact on Higher Education : Institutional and Students' Perspectives. Retrieved from https://www.iau-aiu.net/COVID19-impact-on-Higher-Education-Institutional-and-Students-Perspectives

Junco, R., Merson, D., \& Salter, D. W. (2010). The effect of gender, ethnicity, and income on college students' use of communication technologies. Cyberpsychology, Behavior, and Social Networking, 13(6), 619-627.

Krashen, S. (1982). Principles and practice in second language acquisition. New York: Pergamon Press. 


\section{IJAZ ARAB I}

Journal of Arabic Learning

DOI: $10.18860 / \mathrm{ijazarabi.v4i3.11997}$

ISSN(print): 2620-5912 | ISSN(onIine): 2620-5947

ejournal.uin-malang.ac.id/index.php/ijazarabi/index/608

Kumar, B. A., \& Mohite, P. (2017). Usability of mobile learning applications: a systematic literature review. Journal of Computers in Education, 5, 1-17. https://doi.org/10.1007/s40692-017-0093-6

Lee, M. J. W., \& Chan, A. (2007). Pervasive, lifestyle-integrated mobile learning for distance learners: an analysis and unexpected results from a podcasting study. Open Learning, 22(3), 201-218.

Maatuk, A. M., Elberkawi, E. K., Aljawarneh, S., Rashaideh, H., \& Alharbi, H. (2021). The COVID-19 pandemic and E-learning: challenges and opportunities from the perspective of students and instructors. Journal of Computing in Higher Education, May 2021, 1-18. https://doi.org/10.1007/s12528-021-09274-2

Marinoni, G., Van't Land, H., \& Jensen, T. (2020). The impact of Covid-19 on higher education around the world. IAU Global Survey Report. Retrieved from

https://www.iauaiu.net/IMG/pdf/iau_covid19_and_he_survey_report_fin al_may_2020.pdf

MCMC. (2020). Media Statement: Changing Usage Patterns Influence Internet Speed In Malaysia. Malaysian Communications and Multimedia Commission. Retrieved from https://www.mcmc.gov.my/ms/media/pressreleases/media-statement-changing-usage-patterns-influence

Mohd Amir, R. I., Mohd, I. H., Saad, S., Abu Seman, S. A., \& Tuan Besar, T. B. H. (2020). Perceived Ease of Use, Perceived Usefulness, and Behavioral Intention: The Acceptance of Crowdsourcing Platform by Using Technology Acceptance Model (TAM). In Charting a Sustainable Future of ASEAN in Business and Social Sciences (pp. 403-410). https://doi.org/10.1007/978-981-15-3859-9_34

Pal, D., \& Vanijja, V. (2020). Perceived usability evaluation of Microsoft Teams as an online learning platform during COVID-19 using system usability scale and technology acceptance model in India. Children and Youth Services Review, 119(November), 1-12. https://doi.org/10.1016/j.childyouth.2020.105535

Paudel, P. (2021). Online education: Benefits, challenges and strategies during and after COVID-19 in higher education. International Journal on Studies in Education, 3(2), 70-85.

Traxler, J. (2009). Learning in a mobile age. International Journal of Mobile and Blended Learning (IJMBL), 1(1), 1-12.

United Nation. (2020). Policy Brief: Education during COVID-19 and beyond. https://doi.org/10.24215/18509959.26.e12

Wargadinata, W., Maimunah, I., Febriani, S. R., \& Humaira, L. (2020). Mediated Arabic Language Learning for Arabic Students of Higher Education in COVID-19 Situation. Izdihar: Journal of Arabic Language Teaching, Linguistics, and Literature, 3(1), 59-78. https://doi.org/10.22219/jiz.v3i1.11862 
IJAZ ARABI

Journal of Arabic Learning

DOI: $10.18860 / \mathrm{ijazarabi.v4i3.11997}$

ISSN(print): $2620-5912$ | ISSN(online): $2620-5947$

ejournal.uin-malang.ac.id/index.php/ijazarabi/index/609

World Bank. (2020). The COVID-19 Crisis Response: Supporting tertiary education for continuity, adaptation, and innovation. World Bank, (April). Retrieved

from

https://openknowledge.worldbank.org/handle/10986/34571 